\title{
Survival of foodborne pathogens during frozen storage of cheese made from artificially inoculated milk
}

\author{
Nicolas Metzger ${ }^{1}$ - Avelino Alvarez-Ordóñez ${ }^{1}$. \\ Dara Leong ${ }^{1} \cdot$ Karen Hunt $^{1} \cdot$ Kieran Jordan $^{1}$
}

Received: 27 January 2015 / Revised: 7 April 2015 / Accepted: 4 May 2015 /

Published online: 22 May 2015

(C) INRA and Springer-Verlag France 2015

\begin{abstract}
As cheese is often frozen prior to microbiological analysis, the aim of this study was to determine the survival of foodborne pathogens to freezing in cheese. A semi-soft cheese was produced, in independent triplicate for each pathogen mix, using milk inoculated with two pathogen mixes: Listeria monocytogenes + Staphylococcus aureus and Escherichia coli 0157:H7+Salmonella typhimurium. Three different strains were used for each pathogen, except for E. coli O157:H7 for which two strains were used. Cheeses were manufactured, wrapped in plastic bags and frozen at $-20{ }^{\circ} \mathrm{C}$. For the E. coli $\mathrm{O} 157: \mathrm{H} 7+$ S. typhimurium pathogen mix, the effect of different freezing conditions on survival was studied. In all cases, the numbers of starter bacteria and pathogens were monitored in fresh cheese and after 2, 7, 30 and 90 days of storage. Two methods of thawing were compared after 30 days $\left(14 \mathrm{~h}\right.$ at $4{ }^{\circ} \mathrm{C}$ and $4 \mathrm{~h}$ at $\left.20^{\circ} \mathrm{C}\right)$. The numbers of L. monocytogenes, $S$. aureus and starter bacteria did not change significantly during frozen storage at $-20{ }^{\circ} \mathrm{C}$, but $E$. coli and $S$. typhimurium decreased significantly after 2 days. There was no significant $(p>0.05)$ influence of the thawing method. Freezing of cheese at $-80^{\circ} \mathrm{C}$ or flash freezing in liquid nitrogen only facilitated survival of $E$. coli O157:H7 and S. typhimurium for 1 day. The study shows that cheese samples should not be frozen prior to analysis for detection or enumeration of $E$. coli or S. typhimurium.
\end{abstract}

Keywords Freezing $\cdot$ Cheese $\cdot$ Foodborne pathogens $\cdot$ Survival

\section{Introduction}

It is a relatively common practice to freeze milk or cheese samples prior to microbiological analyses (Ansay and Kaspar 1996; Jakobsen et al. 2009). Many other studies

This paper is part of the Special issue dedicated to the 9th International Cheese Symposium held in Cork, Ireland and organized by Teagasc in collaboration with University College Cork and INRA, 12th \& 13th November 2014.

Kieran Jordan

kieran.jordan@teagasc.ie

$1 \quad$ Teagasc Food Research Centre, Moorepark, Fermoy, Co. Cork, Ireland 
give no information on whether or not samples were frozen. In addition, many researchers do not see any issue with freezing samples prior to microbiological analyses (personal communication). However, some food safety organisations, such as the Food Safety Authority of Ireland, suggest that frozen storage has an impact on the cheese microflora (FSAI 2005). The latest edition of the Standard Methods for the Examination of Dairy Products (Graham 2004) advises not to freeze cheese samples as it could affect microbial populations. The International Commission on Microbiological Specifications for Foods (ICMSF) recommends that cheese samples be stored between 6 and $8{ }^{\circ} \mathrm{C}$ before analysis (ICMSF 1986). There is little data given to support this view, and the view is not universally applied. Freezing is a widely used method for maintaining viability of bacterial cultures, but this is normally achieved with a cryoprotectant, to protect bacteria from the effects of the freeze-thaw process. Freezing bacteria in a food matrix may have detrimental effects on bacterial viability.

Some previous studies have shown that not all bacterial populations survive in frozen conditions in food. Coliform bacteria were sensitive to frozen storage in beef (Luchansky et al. 2012) and in cheese (Ansay and Kaspar 1996). Ben Slama et al. (2012) showed that numbers of Listeria monocytogenes, inoculated onto a sliced cheese surface, decreased by about two log cycles after 6-month frozen storage. Gunnarsdóttir et al. (2012) showed that coliforms and Salmonella were difficult to detect after frozen storage of water, while the numbers of Streptococci and Grampositive bacteria in the water remained stable. In contrast, a study on cheese microflora after 9-month frozen storage showed that the numbers of micrococci and staphylococci tended to decrease over time, while total viable counts, lactic acid bacteria and mouldyeast counts were similar throughout the 9 months (Prados et al. 2004). In a study by Tejada et al. (2006), except for enterococci, counts of microorganisms (including coliforms and Enterobacteriaceae) tended to decrease during 3-, 6- and 9-month frozen storage in cheese. The rate of freezing did not influence the bacterial survival.

In milk, variable results have been obtained with regard to inactivation of pathogens associated with mastitis during frozen storage at $-20{ }^{\circ} \mathrm{C}$. Murdough et al. (1996) and Luedecke et al. (1972) reported no effect of freezing at $-20^{\circ} \mathrm{C}$ for 70 days and 6 weeks, respectively. On the other hand, Schukken et al. (1989), using split samples stored at $-20{ }^{\circ} \mathrm{C}$ for different times, reported a decrease in the number of samples that were positive for Escherichia coli during 16-week storage. Variation in the methodology in these studies makes it difficult to draw any concrete conclusions.

The objective of this study was to determine if freezing at different temperatures $(-20$ and $-80^{\circ} \mathrm{C}$ ), or thawing under different conditions, affected the survival of pathogens during frozen storage of cheese. Four pathogens were monitored in two pathogen combinations, as multiple pathogens can occur in food; a mix of E. coli O157:H7 and Salmonella typhimurium and a mix of Staphylococcus aureus and L. monocytogenes.

\section{Materials and methods}

\subsection{Strains and culture preparation}

Pathogen strains were streaked onto the relevant selective agar [Xylose Lysine Deoxycholate (XLD, Oxoid, Basingstoke, England) for Salmonella; ChromID 
O157 (Biomérieux, Marcy l'Étoile, France) for E. coli O157:H7; Agosti \& Ottaviani Listeria Agar (ALOA; Biomérieux) for L. monocytogenes; Rabbit Plasma Fibrinogen (RPF agar; Oxoid) for S. aureus], and isolated colonies were incubated in Brain-Heart Infusion broth (BHI; Merck, Darmstadt, Germany) at $37{ }^{\circ} \mathrm{C}$ for $14 \mathrm{~h}$. Three strains were used for each pathogen, except for E. coli O157:H7 where two strains were used. The strains of $S$. aureus used were strains 56, 517 and 526, which were isolated from milk, curd and cheese, respectively. The strains of L. monocytogenes used were strain 757, isolated from a clinical study, strain 1020, isolated from raw milk cheese and strain 1021, isolated from the processing environment of a food business. One strain of S. typhimurium was isolated from a pig carcass (strain 3784), while the two others were from American Type Culture Collection (ATCC; Manassas, Virginia, USA): S. typhimurium ATCC 14025 and ATCC BAA-185. The strains of E. coli O157:H7 were the $v t$ negative (non-toxigenic) strains P1432 and NCTC11290 which were isolated from a patient with diarrhoea and obtained from the National Type Culture Collection, respectively.

\subsection{Cheese manufacturing}

A semi-soft cheese was produced using heat-treated milk. The milk (full-fat pasteurised milk) was purchased in a local supermarket (Spar, Fermoy) and was used between 5 and 7 days before the 'use by' date. Fifteen litres of milk was heated to $32^{\circ} \mathrm{C}$ in a vat, with gentle agitation. A sample was removed for microbiological analysis (total bacterial counts and detection/enumeration of the four pathogens being studied). Two hundred microlitres of the relevant pathogen mixture [in 10\% reconstituted skimmed milk (RSM), Kerry Ingredients and Flavour, Charleville, Ireland] were added to the vat, resulting in a concentration of approximately $100 \mathrm{cfu} . \mathrm{mL}^{-}$for each pathogen. A liquid starter culture DPC4268 (Lactococcus lactis 303, Hansens, Cork, Ireland), pre-incubated for $16 \mathrm{~h}$ at $25^{\circ} \mathrm{C}$ in sterile $10 \% \mathrm{RSM}$, was added to the milk at a concentration of $1.5 \%$ when the temperature reached $10^{\circ} \mathrm{C}$. The milk was ripened until the $\mathrm{pH}$ dropped below pH 6.5, when rennet was added (Chymax, Chr. Hansens; $2.5 \mathrm{~mL}$ mixed with $150 \mathrm{~mL}$ of sterile distilled water) under gentle agitation. Curd knives were introduced prior to coagulation, and the milk was left to set for approximately $75 \mathrm{~min}$. The curd was cut into cubes of about $1 \mathrm{~cm}$ cubed and left for $5 \mathrm{~min}$. The cut curd was stirred for $5 \mathrm{~min}$, then cooked to $36^{\circ} \mathrm{C}$ (with a $1^{\circ}$ increase every $5 \mathrm{~min}$ ) and stirred for $30 \mathrm{~min}$ to a $\mathrm{pH}$ of approximately 6.4. One third of the whey was drained, and moulds were filled to obtain 7-8 fresh cheeses. The cheeses were turned every $30 \mathrm{~min}$ for $2 \mathrm{~h}$, then covered with tin foil and left for $15 \mathrm{~h}$. Cheeses were brined for $75 \min (24 \% \mathrm{NaCl}$, $0.02 \% \mathrm{CaCl}_{2}$ ) and allowed to drain for $10 \mathrm{~min}$. The temperature and $\mathrm{pH}$ were recorded at each step to monitor the consistency of the cheese-making process. Cheeses were placed individually (in aerobic conditions) in blender bags, wrapped, labelled and put into a domestic freezer at $-20^{\circ} \mathrm{C}$. Three batches of $7-8$ cheeses were made for each of the two pathogen mixes, in addition to three batches of non-inoculated negative control cheeses. The cheese was made with each pathogen mix on three independent occasions.

To compare the effect of different freezing conditions on pathogen survival, cheeses were manufactured with a mix of the same E. coli 0157:H7 and 
S. typhimurium strains and were frozen at -20 or $-80{ }^{\circ} \mathrm{C}$, or flash-frozen in liquid nitrogen and then stored at $-20{ }^{\circ} \mathrm{C}$. Samples were thawed at room temperature for $4 \mathrm{~h}$ prior to analysis.

\subsection{Sampling and analysis}

The protein, fat and lactose concentrations of the milks were measured by infrared analysis (Milkoscan FT 6000, Foss Electric, Denmark). Determination of the somatic cell count was carried out based on flow cytometry technology (Fossomatic FC 300, Foss Electric, Denmark). Total bacterial count and lactococcal bacterial count were measured by plating the milk on nutrient agar (Oxoid) and L-M17 Agar (Merck KGaA), respectively. Plates were incubated at $37{ }^{\circ} \mathrm{C}$ for $24 \mathrm{~h}$ and at $30{ }^{\circ} \mathrm{C}$ for $48 \mathrm{~h}$, respectively. The presence of Salmonella was detected by sampling $25 \mathrm{~mL}$ of milk into $225 \mathrm{~mL}$ of Buffered Peptone Water (Oxoid), incubated at $37{ }^{\circ} \mathrm{C}$ for $24 \mathrm{~h}$. Then $1 \mathrm{~mL}$ of the mix was transferred into $9 \mathrm{~mL}$ of Rappaport-Vassiliadis Salmonella broth (RVS broth, Oxoid) and incubated at $37{ }^{\circ} \mathrm{C}$ for $24 \mathrm{~h}$. The broth was then plated onto XLD agar plates and incubated at $37^{\circ} \mathrm{C}$ for $24 \mathrm{~h}$. The presence of $E$. coli $\mathrm{O} 157: \mathrm{H} 7$ was detected by sampling $25 \mathrm{~mL}$ of milk into $225 \mathrm{~mL}$ of Modified Tryptone-Soya Broth (MTSB; Oxoid), incubated at $37{ }^{\circ} \mathrm{C}$ for $24 \mathrm{~h}$, then plated onto selective agar (ChromID O157:H7) and incubated at $37^{\circ} \mathrm{C}$ for $24 \mathrm{~h}$. The presence of $L$. monocytogenes was detected by sampling $25 \mathrm{~mL}$ of milk into $225 \mathrm{~mL}$ of half Fraser Broth (Merck $\mathrm{KGaA}$ ), incubated at $30^{\circ} \mathrm{C}$ for $24 \mathrm{~h}$. From this enrichment, $0.1 \mathrm{~mL}$ was inoculated in $10 \mathrm{~mL}$ of full Fraser Broth at $37{ }^{\circ} \mathrm{C}$ for $48 \mathrm{~h}$. From the first and second enrichment broths, $20 \mu \mathrm{L}$ was spread onto ALOA agar and incubated at $37^{\circ} \mathrm{C}$ for $48 \mathrm{~h}$. The presence of $S$. aureus was detected by spreading $0.1 \mathrm{~mL}$ of milk onto a $\mathrm{RPF}$ agar plate which was incubated at $37^{\circ} \mathrm{C}$ for $24-48 \mathrm{~h}$.

Cheeses were thawed at $4{ }^{\circ} \mathrm{C}$ for $14 \mathrm{~h}$. From each cheese, $25 \mathrm{~g}$ was blended with $225 \mathrm{~mL}$ of Trisodium Citrate (TSC; VWR, Leuven, Belgium) and mixed in a Stomacher for $3 \mathrm{~min}$. Starter bacteria, L. monocytogenes, S. aureus, S. typhimurium and E. coli $\mathrm{O} 157: \mathrm{H} 7$ numbers were determined by plating appropriate dilutions on M17 agar, ALOA, RPF agar, XLD agar or ChromID O157:H7 agar, respectively, and incubated at the appropriate temperature, as described above. Numbers were determined at day zero (without freezing) and at days 2, 7, 30 and 90. On each occasion, bacterial counts were determined in quintuple for each pathogen. In order to compare different thawing procedures that could be used in different laboratories, the cheeses were also thawed at $20^{\circ} \mathrm{C}$ for $4 \mathrm{~h}$ on day 30 , and numbers were compared with thawing at $4{ }^{\circ} \mathrm{C}$ for $14 \mathrm{~h}$.

The $\mathrm{pH}$ was measured by inserting a $\mathrm{pH}$ probe (Hanna $\mathrm{pH} 211$, Woonsocket, RI, USA) into the cheeses. Water activity was determined using an AquaLab water activity meter (Series 3 TB, Decagon Devices Inc., Pullman, WA, USA).

\subsection{Statistical analysis}

Three independent replicates of each cheese were made, and bacterial counts were determined by plating five samples from each batch at each sampling point. Data from plate counts (cfu.mL $\mathrm{m}^{-1}$ or $\mathrm{g}^{-1}$ ) were transformed to $\log _{10}$ values and the average and 
standard deviation calculated. The results were analysed using the 'one-way ANOVA' test (GraphPad InStat; Graph Pad Software, La Jolla, CA., USA), with multiple comparisons. Significant differences are reported at a $p$ value of $<0.05$.

\section{Results}

\subsection{Physicochemical characteristics of the milk/cheese}

The fat, protein and lactose concentrations of the milk did not vary in the milk used for manufacturing different cheese batches (data not shown). The physicochemical properties of the cheese batches were similar on all occasions (Table 1) and did not show any evidence of conditions that could influence the survival of bacteria in a different way in the different batches. No pathogens were detected in the milk prior to inoculation, and starter culture numbers in the cheese were consistent over the experimental period at about 9 log cfu.g ${ }^{-1}$ (data not shown).

\subsection{Survival of pathogens at $-20^{\circ} \mathrm{C}$}

During cheese manufacture, the numbers of all pathogens increased, resulting in apparent growth. However, as bacteria concentrate by a factor of approximately tenfold in the curd during the transition from the liquid to the solid phase, this increase in numbers is not necessarily growth. The numbers for each pathogen were $2.76 \pm$ $0.22 \log$ cfu.g ${ }^{-1}$ for L. monocytogenes, $2.39 \pm 0.37 \mathrm{log}$ cfu.g ${ }^{-1}$ for $S$. aureus, $3.63 \pm$ $0.83 \log$ cfu.g ${ }^{-1}$ for E. coli $\mathrm{O} 157: \mathrm{H} 7$ and $3.14 \pm 0.93 \mathrm{log} \mathrm{cfu}^{-g^{-1}}$ for Salmonella in freshly made cheese.

During freezing, there was little or no decrease in L. monocytogenes numbers between fresh cheese and cheese after 2,7 or 30 days at $-20{ }^{\circ} \mathrm{C}$. After 90 days at $-20{ }^{\circ} \mathrm{C}$, the numbers decreased significantly $(p<0.05)$, except that the numbers of $S$. aureus remained constant over the 90-day period in the freezer (Fig. 1). The numbers of $E$. coli $\mathrm{O} 157: \mathrm{H} 7$ and $S$. typhimurium decreased rapidly when cheese was stored at $-20^{\circ} \mathrm{C}$ (Fig. 1). At day 2, S. typhimurium numbers were below the detection limit of the method ( 1 log cfu.g ${ }^{-1}$ ), while E. coli $\mathrm{O} 157: \mathrm{H} 7$ numbers decreased from $3.63 \pm 0.83$ to $2.04 \pm 0.40 \mathrm{log}$ cfu.g ${ }^{-1}$. The numbers of $E$. coli $\mathrm{O} 157: \mathrm{H} 7$ were below the detection limit of the method ( $1 \log$ cfu.g $\left.{ }^{-1}\right)$ at day 7. After 90 days, E. coli O157:H7 were

Table 1 Characteristics of the milk and cheese manufactured with different pathogens added to the cheese/ milk. The value for each batch of cheese manufactured is shown

\begin{tabular}{|c|c|c|c|c|c|c|c|c|c|}
\hline \multirow[b]{2}{*}{ Batch } & \multicolumn{3}{|c|}{ Negative control } & \multicolumn{3}{|c|}{ L. monocytogenes $+S$. aureus } & \multicolumn{3}{|c|}{ E. coli + S. typhimurium } \\
\hline & 1 & 2 & 3 & 1 & 2 & 3 & 1 & 2 & 3 \\
\hline pH (final) & 4.94 & 4.84 & 4.87 & 4.85 & 4.64 & 4.69 & 4.85 & 4.98 & 4.84 \\
\hline Milk temperature & 12 & 12 & 12 & 12 & 12 & 12 & 12 & 12 & 12 \\
\hline Curd temperature & 33 & 31 & 31 & 32 & 32 & 32 & 29 & 29 & 32 \\
\hline $\mathrm{a}_{\mathrm{w}}$ (final) & 0.994 & 0.996 & 0.991 & 0.997 & 0.992 & 0.991 & 0.994 & 0.984 & 0.986 \\
\hline
\end{tabular}




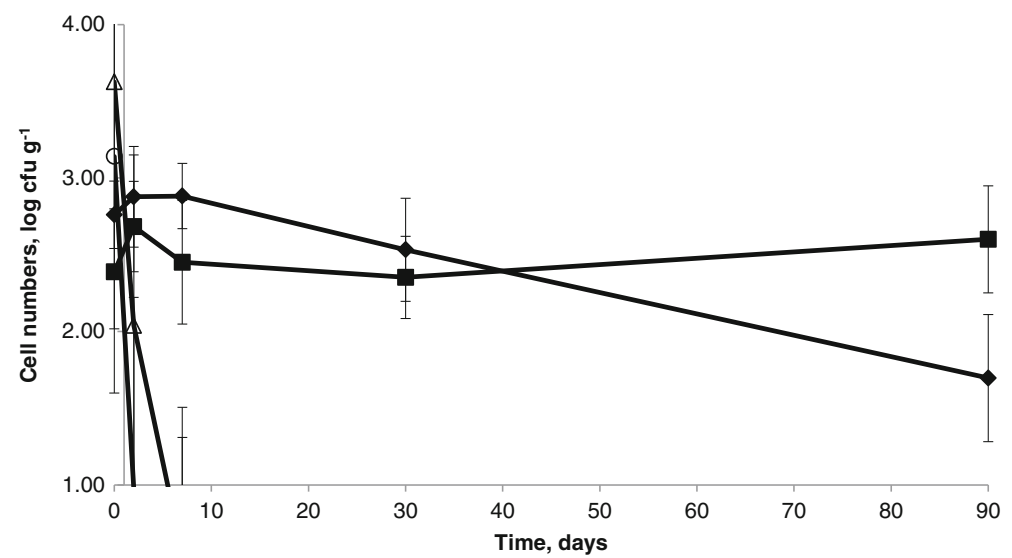

Fig. 1 The effect of freezing at $-20{ }^{\circ} \mathrm{C}$ on the survival of Listeria monocytogenes (black diamond), Staphylococcus aureus (black square), Salmonella typhimurium (white circle) and Escherichia coli O157:H7 (white triangle) in cheese thawed at $4{ }^{\circ} \mathrm{C}$ for $14 \mathrm{~h}$. The average value of five analyses from each of three independent experiments is shown, with the standard deviation as error bars

detectable by enrichment in all cheeses, and S. typhimurium were detectable by enrichment in two of the three batches.

\subsection{Effect of the thawing method on cell viability}

At day 30 , the cheeses were thawed by two different methods $\left(4^{\circ} \mathrm{C}\right.$ for $14 \mathrm{~h}$ or $20{ }^{\circ} \mathrm{C}$ for $4 \mathrm{~h}$ ) and the numbers of starter bacteria, L. monocytogenes and $S$. aureus compared (at this timepoint, the numbers of E. coli $\mathrm{O} 157: \mathrm{H} 7$ and $S$. typhimurium were below the detection limit). The numbers of $L$. monocytogenes were $2.53 \pm 0.34$ and $2.65 \pm 0.25$ when thawed at $4{ }^{\circ} \mathrm{C}$ for $14 \mathrm{~h}$ and $20^{\circ} \mathrm{C}$ for $4 \mathrm{~h}$, respectively, while the numbers of $S$. aureus were $2.35 \pm 0.27$ and $2.25 \pm 0.46$, respectively. The numbers of starter culture were $9.88 \pm 0.41$ and $9.67 \pm 0.44$, respectively. Thus, there was no significant difference $(p>0.05)$ in the counts obtained by the different methods (Fig. 2).

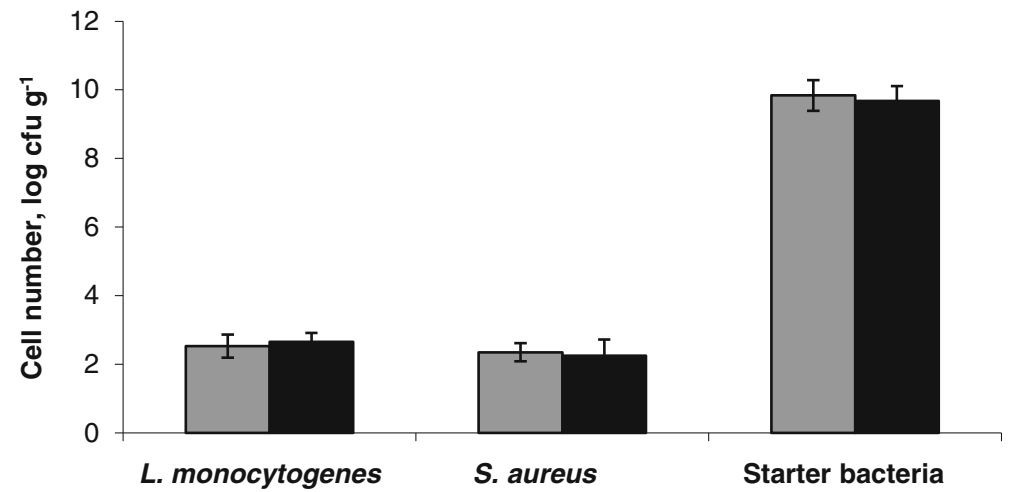

Fig. 2 The effect of thawing at $4{ }^{\circ} \mathrm{C}$ for $20 \mathrm{~h}$ (grey bar) and $20{ }^{\circ} \mathrm{C}$ for $4 \mathrm{~h}$ (black bar) on the survival of Listeria monocytogenes, Staphylococcus aureus and starter bacteria in cheese. The average value of five analyses from each of three independent experiments is shown, with the standard deviation as error bars 


\subsection{Effect of freezing method and temperature}

New batches of cheese were manufactured with the mixture of strains of $E$. coli O157:H7 and S. typhimurium. The cheeses were either kept at $4{ }^{\circ} \mathrm{C}$, frozen at -20 or $-80{ }^{\circ} \mathrm{C}$, or frozen rapidly in liquid nitrogen and kept at $-20{ }^{\circ} \mathrm{C}$. E. coli $\mathrm{O} 157: \mathrm{H} 7$ and $S$. typhimurium behaved similarly. When frozen at $-80{ }^{\circ} \mathrm{C}$, the numbers remained similar to those determined in fresh cheese for 1 day. After 1 day, the numbers decreased rapidly (Fig. 3). When frozen at $-20{ }^{\circ} \mathrm{C}$ or flash-frozen in liquid nitrogen, the numbers were decreased at day 1 compared to the numbers detected in fresh cheese. At day 2, the numbers were below the detection limit of the test $\left(1 \log\right.$ cfu.g $\left.{ }^{-1}\right)$ (Fig. 3).

\section{Discussion}

The results of this study clearly showed that there is a considerable difference in survival of Gram-positive and Gram-negative bacteria during storage of cheese at $-20{ }^{\circ} \mathrm{C}$. The characteristics of the milk and cheese-making process were similar for all batches of cheese, and so the cheese matrix per se did not have any influence on the different survival behaviours of the pathogens. In all cases, similar results were obtained with all three replicates of each pathogen mix. There were some relatively minor differences between the two Gram-positive bacteria. Equal numbers of $S$. aureus were found after 90 days at $-20{ }^{\circ} \mathrm{C}$, whereas the numbers of L. monocytogenes started to decrease slightly after 30 days. Both of the Gram-negative bacteria were considerably decreased after 2 days at $-20{ }^{\circ} \mathrm{C}, \mathrm{S}$. typhimurium to a greater extent. However, in most cases, the Gram-negative bacteria were still detectable by enrichment, even after 90 days of storage.

Normally, vegetative cells of Gram-positive bacteria are more resistant to environmental stresses than vegetative cells of Gram-negative bacteria (Silhavy et al. 2010).

A

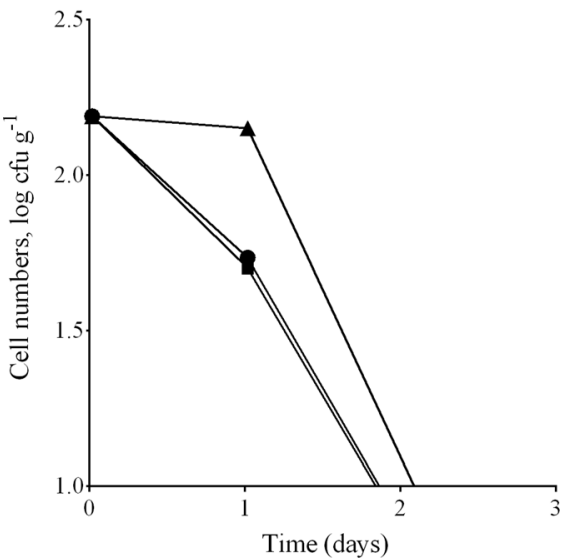

B

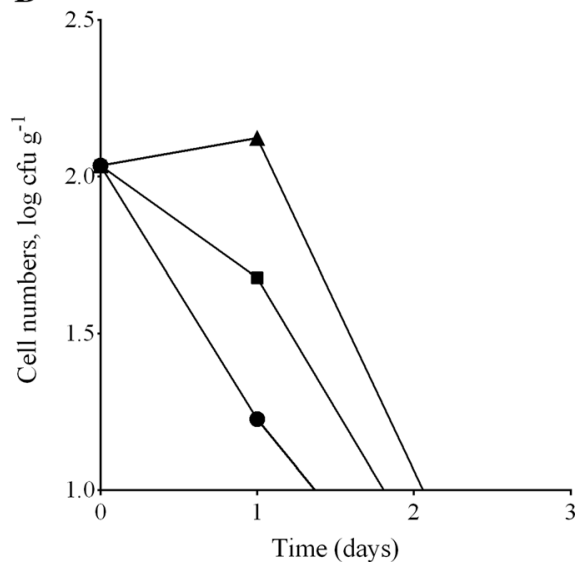

Fig. 3 Effect of freezing at $-20{ }^{\circ} \mathrm{C}$ (black square), $-80{ }^{\circ} \mathrm{C}$ (black triangle) and flash-freezing in liquid nitrogen followed by storage at $-20{ }^{\circ} \mathrm{C}$ (black circle) on the survival of A Salmonella typhimurium and B Escherichia coli $\mathrm{O} 157: \mathrm{H} 7$ in cheese. All counts were below the detection limit $\left(1 \mathrm{log} \mathrm{cfu}^{\left.-\mathrm{g}^{-1}\right)}\right.$ at day 2 . The average values of duplicates are shown, and all values were within $15 \%$ of the average 
The results from the current study showed that this observation also applies to freezing resistance. Indeed, a study by Gunnarsdóttir et al. (2012) showed that coliforms and Salmonella decreased after frozen storage of water, while the numbers of Streptococci and Gram-positive bacteria remained stable. Coliforms have also been shown to be sensitive to frozen storage in beef (Luchansky et al. 2012) and in cheese (Ansay and Kaspar 1996). The difference in survival between Gram-positive and Gram-negative species may be due to the cell wall structure differences between these bacterial groups. Gram-positive bacteria have a cell wall with a thick mucopeptide backbone layer, while Gramnegative bacteria have a thin middle membrane which would provide minor protection against stress. In addition, as the cheeses had a high water activity $(0.993 \pm 0.004)$, this water could increase the pressure within the cheese when freezing, leading to a greater effect on Gram-negative bacteria. The presence of lactic acid has been shown to act as a permeabiliser to the outer membrane of Gram-negative bacteria, including E. coli O157:H7 and S. typhimurium (Alakomi et al. 2000). Thus, lactic acid present in cheese could enhance the deleterious effect of freezing on the cell.

Freezing at $-80{ }^{\circ} \mathrm{C}$ degrees is considered to promote better survival of bacteria. Rapid freezing (for example in liquid nitrogen) is another strategy that may increase survival of bacteria. However, neither of these strategies increased the survival of E. coli $\mathrm{O} 157: \mathrm{H7}$ or S. typhimurium in cheese (Fig. 3).

As each cheese was inoculated with a mixture of pathogens, it is possible that there were interspecies interactions that influenced survival (Ronan et al. 2013). However, in reality, the occurrence of two pathogens in the same cheese is likely; therefore, this method of artificial inoculation was used. Further experiments would be required to eliminate the possibility of interactions between the pathogens.

Freezing cheese samples prior to analysis for Gram-negative bacteria will compromise the results. The idea that cheese samples can be frozen prior to analysis may have arisen from an increase in emphasis on molecular studies. Detection of DNA will not be compromised by freezing, so there is a need to re-emphasise that molecular studies are different from studies focused on detection or enumeration of viable cells, which may be compromised by freezing the samples.

Freezing samples for chemical analysis is also widely practiced. The results of this study emphasise that data on the effect of freezing on the analyte being measured should be obtained in order to design a freezing strategy that does not compromise the analysis. For example, Power et al. (2013) showed that freezing samples prior to analysis of flukicides compromises the results for analysis of these residues.

\section{Conclusions}

From this study, it can be concluded that cheese samples should not be frozen prior to analysis for detection or enumeration of E. coli O157:H7 and S. typhimurium, but samples can be frozen prior to analysis of $S$. aureus and L. monocytogenes, although the time for freezing samples prior to L. monocytogenes analysis should not exceed 30 days. Further study is required to determine if this freezing strategy can be extended to other foods. 
Acknowledgments The authors wish to acknowledge the funding support from the Food Institutional Research Measure of the Irish Department of Agriculture, Food and the Marine, grant number 11F008. Nicolas Metzger received support from the ERASMUS scheme. A. Alvarez-Ordóñez is a Starting Investigator Research Fellow funded by the Science Foundation Ireland (SFI) under grant number 13/SIRG/2157.

Conflict of interest The authors declare that they have no competing interests.

\section{References}

Alakomi H-L, Skyttä E, Saarela M, Mattila-Sandholm T, Latva-Kala K, Helander IM (2000) Lactic acid permeabilizes Gram-negative bacteria by disrupting the outer membrane. Appl Environ Microbiol 66: 2001-2005

Ansay S, Kaspar C (1996) Survey of retail cheeses, dairy processing environments and raw milk for Escherichia coli O157:H7. Lett Appl Microbiol 25:131-134

Ben Slama R, Miladi H, Chaieb K, Bakhrouf A (2012) Survival of Listeria monocytogenes cells and the effects of extended frozen storage $\left(-20^{\circ} \mathrm{C}\right)$ on the expression of its virulence gene. Appl Biochem Biotechnol 170:1174-1183

Food Safety Authority of Ireland (2005) The control and management of Listeria monocytogenes contamination of food. Published by the Food Safety Authority of Ireland, Abbey Court, Dublin, Available at: https://www.fsai.ie/WorkArea/DownloadAsset.aspx?id=1234. Accessed 13 Jan 2015

Graham T (2004) Sampling dairy and related products. In: Wehr M, Frank J (eds) Standard methods for the examination of dairy products, 17th edn. J. American Public Health Association, pp 63-92

Gunnarsdóttir R, Müller K, Jensen PD, Villumsen A (2012) Effect of long-term freezing and freeze-thaw cycles on indigenous and inoculated microorganisms in dewatered blackwater. Environ Sci Technol 46: $12408-12416$

International Commission on Microbiological Specifications for Foods (1986) Microorganisms in food 2: sampling for microbiological analysis: principles and specific applications, 2nd edn. Blackwell Scientific Publications

Jakobsen R, Heggebø R, Sunde E, Skjervheim M (2009) Staphylococcus aureus and Listeria monocytogenes in Norwegian raw milk cheese production. Food Microbiol 28:492-496

Luchansky B, Porto-Fett A, Shoyer B, Phillips J, Chen V, Eblen D, Cook V, Mohr T, Esteban E, Bauer N (2012) Fate of Shiga toxin-producing O157:H7 and non-O157:H7 Escherichia coli cells within refrigerated, frozen or frozen then thawed ground beef patties cooked on a commercial open-flame gas or a clamshell electric grill. J Food Prot 76:1500-1512

Luedecke LO, Forster TL, Williams K, Hillers JK (1972) Effect of freezing and storage at $-20{ }^{\circ} \mathrm{C}$ on survival of mastitis pathogens. J Dairy Sci 55:417-418

Murdough PA, Deitz KE, Pankey JW (1996) Effects of freezing on the viability of nine pathogens from quarters with subclinical mastitis. J Dairy Sci 79:334-336

Power C, Sayers R, O’Brien B, Furey A, Danaher M, Jordan K (2013) Review of studies on flukicide residues in cows' milk and their transfer to dairy products. Irish J Agric Food Res 52:197-207

Prados F, Pino A, Rincón F, Vioque M, Fernández-Salguero J (2004) Influence of the frozen storage on some characteristics of ripened Manchego-type cheese manufactured with a powered vegetable coagulant and rennet. Food Chem 95:677-682

Ronan E, Yeung CW, Hausner M, Wolfaardt GM (2013) Interspecies interaction extends bacterial survival at solid-air interfaces. Biofouling 29:1087-1096

Schukken YH, Leslie KE, Barnum DA, Mallard BA, Lumsden JH, Dick PC, Vessie GH, Kehrli ME (1989) Experimental Staphylococcus aureus intramammary challenge in late lactation dairy cows: quarter and cow effects determining the probability of infection. J Dairy Sci 82:2393-2401

Silhavy TJ, Kahne D, Walker S (2010) The bacterial cell envelope. Cold Spring Harb Perspect Biol 2:a000414

Tejada L, Sánchez E, Gómez R, Vioque M, Fernández-Salguero J (2006) Effect of freezing and frozen storage on chemical and microbiological characteristics in sheep milk cheese. J Food Sci 67:126-129 